\title{
The Assessment of Patient Satisfaction and Attendance of Community Pharmacies in Slovakia
}

Comenius University in Bratislava, Faculty of Pharmacy, Department of Organisation and Management in Pharmacy, Odbojarov 10, 83232 Bratislava, Slovak Republic.

Univerzita Komenského v Bratislave, Farmaceutická fakulta, Katedra organizácie a riadenia farmácie, Odbojárov 10, 832 32 Bratislava, Slovenská republika.

Received June 2, 2016, accepted 5 July, 2016

Abstract Aim: Patient-oriented pharmaceutical care in pharmacies could improve patient satisfaction and influence patient's choice of a community pharmacy. The aim of the work was to assess patient satisfaction and attendance in community pharmacies in Slovakia. Methods: A self-administered, anonymous questionnaire was distributed to patients visiting 33 community pharmacies in a total of 23 Slovak cities during October-December 2013. The questionnaire contained 29 items and three dimensions were supposed (managing therapy, interpersonal relationship, general satisfaction). A 5-point Likert-type scale $(1=$ very satisfied, $2=$ satisfied, 3 = neither satisfied nor dissatisfied, $4=$ dissatisfied, 5 = very dissatisfied) was used for assessing patient satisfaction. The results are presented in percentages and by the level of satisfaction within the range: high satisfaction (score 1.00-2.50), moderate satisfaction (score 2.51-3.50) and low satisfaction (score 3.51-5.00). Reasons for attendance in the community pharmacy and factors influencing pharmacy choice were evaluated either. Results: A total 2844 respondents were included into the survey. Patient satisfaction with pharmaceutical care achieved high satisfaction level: interpersonal relationship (1.85 \pm $0.598 ; 86.7 \%$ highly satisfied respondents) and general satisfaction ( $2.02 \pm 0.643 ; 71.3 \%$ highly satisfied respondents). Managing therapy scored lower $(2.24 \pm 0.704 ; 65.4 \%$ highly satisfied respondents). The most frequently reported reasons for attending community pharmacy were to obtain prescription (70.4\%) and over-the-counter medications (70.4\%). The patient choice of a particular pharmacy was influenced by its location (74.1\%). Conclusion: This study presents the first nationwide patientreported outcomes about patient satisfaction and attendance in community pharmacies in Slovakia. Future development and advancement of pharmacy practice leading to higher patient satisfaction requires modification of community pharmacists' professional behaviour in Slovakia namely in managing therapy of patients.

Slovak Ciel:Zavedenie lekárenskej starostlivosti orientovanej na pacienta v lekárňach by mohlo zlepšit pacientsku spokojnost’ a ovplyvnit abstract výber verejnej lekárne pacientom. Ciel'om práce bolo zhodnotit' pacientsku spokojnost' a návštevnost' verejných lekární na Slovensku. Metódy: anonymný dotazník na samostatné vyplnenie sa distribuoval pacientov, ktorí navštívili 33 verejných lekární v celkom 23 slovenských mestách v období október - december 2013. Dotazník obsahoval 29 otázok a predpokladali sa tri dimenzie (manažment liečby, interpersonálne vztahy, všeobecná spokojnos). Pri hodnotení sa použila 5-stupňová Likertova škála (( 1 = vel'mi spokojný, 2 = spokojný, 3 = ani spokojný, ani nespokojný, 4 = nespokojný, 5 = vel'mi nespokojný).Výsledky sú prezentované percentami a úrovňou spokojnosti v rozmedzí: vysoká spokojnost' (skóre 1,00 - 2,50), priemerná spokojnost' (skóre 2,51 - 3,50) a nízka spokojnost' (skóre 3,51 - 5,00). Hodnotili sa aj dôvody návštevy verejnej lekárne a faktory ovplyvňujúce výber lekárne. Výsledky: Prieskumu sa zúčastnilo spolu 2844 respondentov. Pacientska spokojnost' s lekárenskou starostlivostou dosiahla vysokú úroveň: interpersonálne vztahy $(1,85 \pm 0,598 ; 86,7 \%$ vysoko spokojných respondentov) iba a všeobecná spokojnost'. $(2,02 \pm 0,643 ; 71,3 \%$ vysoko spokojných respondentov). Manažment liečby bol hodnotený nižšie $(2,24 \pm 0,704 ; 65,4 \%$ vysoko spokojných respondentov). Najčastejším dôvodom návštevy verejnej lekárne bola potreba získat' lieky na recept (70,4\%) a lieky bez lekárskeho predpisu (70,4\%).Výber konkrétnej lekárne pacientom ovplyvňovala jej lokalita (74,1\%).Záver: Štúdia predstavuje prvé celoslovenské pacientmi oznámené výsledky o ich spokojnosti a návštevnosti verejných lekární. Budúci vývoj a pokrok v lekárenskej praxi, vedúci k vyššej pacientskej spokojnosti, vyžaduje modifikáciu profesionálneho správania sa lekárnikov na Slovensku najmä v oblasti manažmentu liečby pacientov.

Keywords Pharmaceutical care-Community pharmacy-Patient satisfaction-Managing therapy-Pharmacy choice-Patient-reported outcomes

Klúčové lekárenská starostlivost'-verejná lekáreň - pacientska spokojnost'- manažment liečby - výber lekárne - pacientom oznámené výsledky slová:

\section{INTRODUCTION}

Pharmacists are the most accessible health care professionals and play a key role in the delivery of health care services, particularly in ensuring effective and safe treatment. In the era of rapidly accelerating changes in health care delivery, the roles of pharmacists are constantly being redefined (European Community Pharmacy Blueprint, 2012). During the past years, the pharmacist's role has grown and changed to encompass areas beyond the function of dispensing medications. The

*E-mail:minarikova@fpharm.uniba.sk

(c) European Pharmaceutical Journal 
new role is based on the concept of changing the pharmacist's focus from drug providing and distributing services to more patient-oriented approaches (Hepler \& Strand, 1990) with positive impact on patient outcomes (Armour et al, 2007, Nkansah et al, 2010). Despite the fact that the concept of new pharmaceutical care is now widely accepted by pharmacists, there are serious barriers in implementation of this concept in real pharmaceutical practice (Van Mil, 2001).

The transition to a market-oriented economy in Slovakia, like other Eastern European countries, caused changes in the healthcare system and affected all its aspects, including pharmacy care, pharmacy services, pharmacist's role and expectations and patient's behaviour (Volmer et al. 2009). While the total number of pharmacists in the year 1999 was 2 175 (Health Statistics Yearbook of the Slovak Republic, 1999), today this is higher than twice that number. According to the Slovak Chamber of Pharmacists, 4419 pharmacists and 1 972 pharmacies are currently in Slovakia (Slovak Chamber of Pharmacists, 2015). With density of 822 pharmacists and 366 pharmacies per 10000 inhabitants, Slovakia is comparable with other European countries (International Pharmaceutical Federation Global Pharmacy Workforce Report, 2012). The distribution of pharmacies in Slovakia shows regional disparities. The number of pharmacies and pharmacists is not regulated and it dramatically increased as a result of legislative changes and liberalisation of ownership regulation, which enables non-pharmacists to own pharmacies. It is estimated that about $70 \%$ of all pharmacies in Slovakia are part of some or the other pharmacy chains (Szalayová et al. 2014). Community pharmacies are privately owned in Slovakia, they run on a profit basis and are not subsidised by the state. All prescription $(\mathrm{Rx})$ and non-prescription (over-the-counter $=\mathrm{OTC}$ ) medicines can be purchased only from community pharmacy (Szalay et al. 2011). The significant market competition together with regulatory arrangements, represent indirect factors that affect the financial-economic situation of pharmacies as business entities (Malovecka et al. 2015, Vogler et al. 2012,).

There is no doubt that community pharmacies must now try to create new image by overcoming the perception of pharmacist as medicine dispenser to professional provider of healthcare goods and services oriented to patient needs with the aim of fully satisfying them. Pharmacists who can demonstrate greater patient satisfaction may be at a competitive advantage. Patient satisfaction becomes an important indicator of availability and quality of provided care (Cleary \& McNeil, 1988, Kucukarslan \& Schommer, 2002). Sitzia and Wood emphasise that effectiveness of medical care should not be expressed only by clinical and economic parameters, but as well by patient opinions in assessment of this care (Sitzia \& Wood, 1997). There are strong evidences that patient satisfaction is linked with better medication compliance, clinical outcomes (Kane et al. 1997, Ware \& Davies, 1983), patient loyalty with care providers (Garman et al. 2004, Oparah \& Kikanme, 2006) and with continuously using health care service (Zastowny et al. 1989).
Collecting data by using available instruments to measure patient satisfaction is valuable for continuous quality improvement to identify variations, trends and patterns. Published studies from developed countries concentrate on patient satisfaction with pharmaceutical care (Naik Panvelkar et al. 2009) or with specific disease management (Armour et al. 2007). There are also data that show positive correlation between patient choice of pharmacy, provided pharmaceutical care and loyalty of patients (Merks et al. 2014). It seems that consistently applied pharmaceutical care can influence the patient's choice of pharmacy and also patient satisfaction. Similar data from Slovakia are still inadequate.

This study presents the first Slovak nationwide patientreported outcomes about patient satisfaction with pharmaceutical care provided in community pharmacies. An additional objective was to identify reasons of pharmacy attendance and determine factors that influence patient's choice of community pharmacy in Slovakia.

\section{METHODS}

This is a cross-sectional study utilising self-administered questionnaire. The survey questionnaire was developed from published studies (Larson et al. 2002, Traverso et al. 2007). All items were translated to Slovak language using a forward backward method and randomly assigned. Three dimensions were proposed: managing therapy (16 items), interpersonal relationship (9 items) and general satisfaction (4 items). A 5-point Likert-type scale (1 = very satisfied, $2=$ satisfied, 3 = neither satisfied nor dissatisfied, $4=$ dissatisfied, 5 = very dissatisfied) was used to measure the extent of patient satisfaction with the pharmaceutical care provided in community pharmacies. To evaluate patient attendance in community pharmacy, the respondents were inquired about their reasons for visiting a community pharmacy and the factors that make them choose a particular pharmacy. Respondents could indicate more than one given options. Finally, sociodemographic and health characteristics were included into the questionnaire. The questionnaire was first applied in a pilot test (10 patients) for clarity, relevance, acceptability and time to completion. Refinements were made to the survey accordingly. The results from pilot testing were not included in the main study.

The participants of the survey were asked by the specially educated students from Faculty of Pharmacy of the Comenius University in Bratislava to give oral permission for participation in the survey and answer the self-administered questionnaire, explaining to them that it was voluntary and confidential. No inclusion or exclusion criteria were predetermined. Data collection took place over an 8-week period between October and December 2013 in a total of 33 community pharmacies in 23 different Slovak cities. The selection of pharmacies was random and reflected the actual possibilities of research organiser and the agreement of pharmacy. 
Table 1. Characteristics of study respondents $(n=2844)$

\begin{tabular}{|c|c|c|}
\hline \multicolumn{2}{|c|}{ Characteristics } & Frequency (\%) \\
\hline \multirow{2}{*}{$\begin{array}{c}\text { Gender } \\
(\mathrm{N}=2841)^{\mathrm{a}}\end{array}$} & Male & $944(33.2)$ \\
\hline & Female & $1897(66.8)$ \\
\hline \multirow{3}{*}{$\begin{array}{l}\text { Age (years) } \\
(\mathrm{N}=2844)^{\mathrm{a}}\end{array}$} & $\leq 30$ & $801(28.2)$ \\
\hline & $31-60$ & $1531(53.8)$ \\
\hline & $\geq 61$ & $512(18.0)$ \\
\hline \multirow{3}{*}{$\begin{array}{l}\text { Level of education } \\
\qquad(\mathrm{N}=2799)^{\mathrm{a}}\end{array}$} & $\begin{array}{c}\text { Primary } \\
\text { school }\end{array}$ & $187(6.7)$ \\
\hline & $\begin{array}{l}\text { Secondary } \\
\text { school }\end{array}$ & 1649 (58.9) \\
\hline & High school & $963(34.4)$ \\
\hline \multirow{3}{*}{$\begin{array}{l}\text { Number of Rx or OTC } \\
\text { drugs during the last } \\
\text { month } \\
\qquad(N=2832)^{\mathrm{a}}\end{array}$} & 0 & $474(16.7)$ \\
\hline & $1-2$ & 1198 (42.3) \\
\hline & $\geq 3$ & $1160(41.0)$ \\
\hline \multirow{3}{*}{$\begin{array}{l}\text { Number of prescriptions } \\
\text { during the last } 3 \text { months } \\
\qquad(N=2829)^{\text {a }}\end{array}$} & 0 & $830(29.3)$ \\
\hline & $1-2$ & 1215 (42.9) \\
\hline & $\geq 3$ & $784(27.7)$ \\
\hline \multirow{3}{*}{$\begin{array}{l}\text { Number of pharmacies } \\
\text { visited during the last } 3 \\
\text { months }(\mathrm{N}=2812)^{\mathrm{a}}\end{array}$} & 1 & $1269(45.1)$ \\
\hline & 2 & $1054(37.5)$ \\
\hline & $\geq 3$ & $490(17.4)$ \\
\hline \multirow{2}{*}{$\begin{array}{l}\text { Long-term use of } \\
\text { medicines }(\mathrm{N}=2835)^{\mathrm{a}}\end{array}$} & Yes & $1279(45.1)$ \\
\hline & No & 1556 (54.9) \\
\hline \multirow{3}{*}{$\begin{array}{l}\text { Average monthly } \\
\text { expenditure for } \\
\text { medicines and other } \\
\text { goods from the } \\
\text { pharmacy (euro) } \\
(\mathrm{N}=2833)^{\mathrm{a}}\end{array}$} & $<10$ & 1237 (43.7) \\
\hline & $10-30$ & $1149(40.6)$ \\
\hline & $>30$ & $447(15.8)$ \\
\hline \multirow{4}{*}{$\begin{array}{c}\text { City (number of } \\
\text { inhabitants) (2 844) }\end{array}$} & $>100000$ & $326(11.5)$ \\
\hline & $<100000$ & $557(19.6)$ \\
\hline & $<50000$ & $957(33.6)$ \\
\hline & $<20000$ & 1004 (35.3) \\
\hline
\end{tabular}

${ }^{a}$ Not all respondents completed every item. $N=$ number of respondents completing the item.

All questionnaires were analysed regardless of the completeness of questionnaire; therefore, the actual evaluated numbers are different from the total number of respondents ( $n=2844$ ). After coding and checking the questionnaires for accuracy, they were statistically analysed using the Statistical Package for Social Sciences (SPSS) version 19.0 for Windows. Frequency and percentage statistics were used to represent results. In order to present patient satisfaction in a measurable way, scoring of responses was done for all items as the mean score and standard deviations according to original 5-point Likert scale. Calculated scores were collapsed into three satisfaction levels (high satisfaction $=$ range of score 1.002.50 , moderate satisfaction $=$ range of score 2.51-3.50, low satisfaction $=$ range of score $3.51-5.00$ ).

\section{RESULTS}

\section{General characterisation of survey}

During the 8-week study period, 2844 respondents answered the survey. Their characteristics are summarised in Table 1. The mean age was 44.0 years with a standard deviation of 17.1 years. A total of $53.8 \%$ participants were in the $31-60$ years age group. The majority of the participants $(66.8 \%)$ were females, $58.9 \%$ had completed a secondary education. From the total number of study respondents, $11.5 \%$ were from cities with more than 100000 inhabitants (only two cities in Slovakia), $19.6 \%$ were from cities with up to 100000 inhabitants, 33.6\% were from cities with up to 50000 inhabitants and $35.3 \%$ were from cities with up to 20000 inhabitants. From the total number, $42.3 \%$ of participants had one or two medicines and $41.0 \%$ had three or more medicines during last month (either Rx or OTC drugs). As physicians can prescribe medicines for longer time, the number of prescriptions can be lower. Only $27.2 \%$ of the participants had three or more prescriptions during the last 3 months, $42.9 \%$ had one or two prescriptions and $29.3 \%$ had no prescriptions during the last 3 months. Long-term use of medicines (for example, drugs for chronic diseases, such as diabetes, hypertension and others) were used by $45.1 \%$ of respondents. Our data show that respondents usually do not attend many pharmacies. Only $17.4 \%$ of the respondents visited three or more pharmacies during the last 3 months, the rest of respondents visited only one or two. With the wide availability of the pharmacies, this finding can be an indirect indicator of the patient's satisfaction - satisfied patient does not need to visit more pharmacies to fulfil his/ her requirements. $43.7 \%$ of our respondents stated that their average monthly expenditures for pharmaceutical products (it means co-payment on Rx products, OTC drugs, other goods in pharmacy) are less than 10 euro, $40.6 \%$ spent from $10-30$ euro, but $15.8 \%$ spent more than 30 euro in average per month.

\section{Patient attendance of community pharmacies}

The main reasons for visiting pharmacy are shown in Table 2. The two main stated reasons for visiting community pharmacy were to obtain prescription medication (70.4\%) and over-thecounter medications (70.4\%). Due to counselling and using pharmaceutical services, only $12.0 \%$ and $4.5 \%$ of respondents separately reported visiting community pharmacy.

The main factors influencing the choice of any particular pharmacy are in Table 3. The primary factor was the pharmacy location (74.1\% of respondents) followed by good experience with the pharmacy $(49.3 \%$ of respondents). The less 
Table 2. Main reasons for visiting a community pharmacy ( $n=$ 2844)

\begin{tabular}{|c|c|}
\hline $\begin{array}{c}\text { Main factors for visiting community } \\
\text { pharmacy }\end{array}$ & $\begin{array}{c}\text { Frequency } \\
\text { (\%) }\end{array}$ \\
\hline To obtain prescription medications & $\mathbf{2} 001$ (70.4) \\
\hline $\begin{array}{c}\text { To obtain over-the-counter medications and } \\
\text { food supplements }\end{array}$ & $\mathbf{2} 001(\mathbf{7 0 . 4 )}$ \\
\hline $\begin{array}{c}\text { To obtain other products (cosmetics, baby } \\
\text { care products ...) }\end{array}$ & $\mathbf{7 8 6}(\mathbf{2 7 . 6 )}$ \\
\hline Counselling & $\mathbf{3 4 2 ( 1 2 . 0 )}$ \\
\hline $\begin{array}{c}\text { Pharmacy services (measure blood pressure, } \\
\text { cholesterol ...) }\end{array}$ & $\mathbf{1 2 7 ( 4 . 5 )}$ \\
\hline Other & $\mathbf{3 9}(\mathbf{1 . 4 )}$ \\
\hline
\end{tabular}

Table 3. Factors influencing the choice of any particular pharmacy $(n=2844)$

\begin{tabular}{|c|c|}
\hline $\begin{array}{c}\text { Factors influencing the choice of any } \\
\text { particular pharmacy }\end{array}$ & $\begin{array}{c}\text { Frequency } \\
\text { (\%) }\end{array}$ \\
\hline Pharmacy location & $\mathbf{2} 106(74.1)$ \\
\hline Good experience with the pharmacy & $1401(49.3)$ \\
\hline Qualified and friendly staff & $913(32.1)$ \\
\hline $\begin{array}{c}\text { Convenient working hours } \\
\text { Pharmacy services (measure blood pres- } \\
\text { sure, cholesterol ...) }\end{array}$ & $1979(20.4)$ \\
\hline Self-service area & $76(2.7)$ \\
\hline Other reasons & $66(2.3)$ \\
\hline
\end{tabular}

important factor was qualified and friendly staff of pharmacy (32.1\% of respondents) and convenient working hours (20.4\% of respondents). Self-service area was a considerable factor influencing the choice of pharmacy only for $2.7 \%$ of respondents.

\section{Patient satisfaction with pharmaceutical care provided in community pharmacies}

This section consisted of a total 29 items that reflected patient's satisfaction with three dimensions of pharmaceutical care. Table 4 shows these results. The mean calculated score ranged from 1.26 to 2.45 . High satisfaction level was achieved in all dimensions: the highest with interpersonal relationship (1.85 $\pm 0.598 ; 86.7 \%$ highly satisfied respondents), the lowest with managing therapy $(2.24 \pm 0.704 ; 65.4 \%$ highly satisfied respondents). Only $3.5 \%$ respondents indicated low satisfaction and $31.1 \%$ moderate satisfaction with managing therapy. From the total items, only eight of them had the mean score more than 2.00 (one item in general satisfaction, two items in interpersonal relationship and five items in managing therapy). All other items achieved mean score under 2.00 .

The most positively evaluated item was 'The availability of the pharmacist to answer your questions' from managing therapy (1.26 $\pm 0.704 ; 88.2 \%$ highly satisfied respondents), then 'The wayhow pharmacistanswersyourquestions', from interpersonal relationship ( $1.63 \pm 0.733 ; 90.1 \%$ highly satisfied respondents) and 'The professional appearance of the pharmacy', from general satisfaction $(1.63 \pm 0.765 ; 88.8 \%$ highly satisfied respondents). The following items recorded the lowest scores: 'The privacy of your conversations with the pharmacist' from general satisfaction $(2.45 \pm 1.110 ; 53.6 \%$ highly satisfied respondents), 'How frequently the pharmacist checks with you about how well your medications are working' $(2.31 \pm 1.118$; $40.2 \%$ highly satisfied respondents) and 'How your pharmacist uses information about your previous conditions/drugs when assessing your drug therapy' $(2.28 \pm 1.181 ; 44.0 \%$ highly satisfied respondents), both from managing therapy.

\section{DISCUSSION}

To the best of our knowledge, ours was the first effort to evaluate the patient satisfaction with pharmaceutical care provided in community pharmacies in Slovak republic. Our previous pilot study presented a high patients' satisfaction and the professional and human approach of pharmacists was identified as the key factors of patients' satisfaction (Minarikova et al. 2015). For this assessment, we used validated questionnaires (Larson et al. 2002, Traverso et al. 2007). Their instrumentscontained twomaindimensions of pharmaceutical care that relate to satisfaction (friendly explanation and managing therapy). They evaluated cumulative experience of patients with comprehensive pharmaceutical care practice in community pharmacies and they could be applied in community pharmacies offering pharmaceutical care as well as traditional pharmacy services, which are dominant in Slovak conditions. Our survey results generally showed a high patient satisfaction with pharmaceutical care provided in the Slovak community pharmacies, particularly in the term of interpersonal relationship. This finding is consistent with other published studies. Alturki et al. (Alturki et al. 2013) showed a 'good consumer satisfaction' with the pharmacy encounters in Kingdom of Saudi Arabia. The items that received high satisfaction scores were pharmacist was always available, pharmacist provides thorough explanations/clear labelling of drugs, pharmacist politeness and prompt. Other studies also demonstrated that a pharmacist's personality, competence and ability to reach to a patient could positively influence a patient's decision to choose a particular pharmacy and her/ his satisfaction (Hasan et al. 2013). According to our results, managing therapy was rated with the lowest score. The respondents were more dissatisfied nearly with all items from this dimension. This finding was not surprising because specific 
Table 4. Survey items and patients satisfaction

\begin{tabular}{|c|c|c|c|c|}
\hline \multirow{2}{*}{ Item/Dimension of pharmaceutical care } & \multicolumn{3}{|c|}{$\%$ respondents rating as } & \multirow{2}{*}{$\begin{array}{l}\text { Mean score } \\
\quad \pm \text { SD }\end{array}$} \\
\hline & HS & MS & LS & \\
\hline Managing therapy & 65.4 & 31.1 & 3.5 & $2.24 \pm 0.704$ \\
\hline The availability of the pharmacist to answer your questions. & 88.2 & 9.2 & 2.6 & $1.26 \pm 0.730$ \\
\hline The way the pharmacist helps you to manage your medications. & 58.7 & 35.1 & 6.2 & $1.89 \pm 1.083$ \\
\hline $\begin{array}{l}\text { How frequently the pharmacist checks with you about how well your } \\
\text { medications are working. }\end{array}$ & 40.2 & 48.3 & 11.5 & $2.31 \pm 1.118$ \\
\hline The pharmacist's efforts to help you improve your health or stay healthy. & 60.4 & 33.6 & 6.0 & $1.85 \pm 1.076$ \\
\hline $\begin{array}{c}\text { The information the pharmacist gives you about the proper storage of } \\
\text { your medication. }\end{array}$ & 68.9 & 23.8 & 7.3 & $1.69 \pm 1.061$ \\
\hline $\begin{array}{l}\text { The pharmacist's efforts to solve problems that you have with your medi- } \\
\text { cation. }\end{array}$ & 68.4 & 27.4 & 4.2 & $1.67 \pm 1.009$ \\
\hline $\begin{array}{l}\text { The written information the pharmacist provides you about drug therapy } \\
\text { and/or diseases. }\end{array}$ & 57.3 & 35.2 & 7.5 & $1.93 \pm 1.104$ \\
\hline $\begin{array}{l}\text { The information the pharmacist gives you about the results you can ex- } \\
\text { pect from your drug. }\end{array}$ & 65.2 & 27.8 & 7.0 & $1.77 \pm 1.075$ \\
\hline $\begin{array}{l}\text { The pharmacist's help when a medication does not have the expected } \\
\text { effect. }\end{array}$ & 55.5 & 38.7 & 5.8 & $1.95 \pm 1.082$ \\
\hline $\begin{array}{l}\text { How your pharmacist uses information about your previous conditions/ } \\
\text { drugs when assessing your drug therapy. }\end{array}$ & 44.0 & 40.3 & 15.7 & $2.28 \pm 1.181$ \\
\hline $\begin{array}{l}\text { The help you get from the pharmacy staff with the administrative ar- } \\
\text { rangements necessary to obtain your medicines. }\end{array}$ & 48.6 & 43.8 & 7.5 & $2.10 \pm 1.103$ \\
\hline $\begin{array}{l}\text { The way your pharmacist works together with you to plan what should } \\
\text { be done to get good results from your medications. }\end{array}$ & 58.4 & 34.8 & 6.8 & $1.90 \pm 1.095$ \\
\hline $\begin{array}{l}\text { The way your pharmacist works together with your doctor to make sure } \\
\text { your medications are the best for you. }\end{array}$ & 47.3 & 42.3 & 10.4 & $2.16 \pm 1.135$ \\
\hline The responsibility that the pharmacist assumes for your drug therapy. & 45.6 & 44.9 & 9.5 & $2.18 \pm 1.118$ \\
\hline How well the pharmacist explains possible side effects. & 65.8 & 24.4 & 9.8 & $1.78 \pm 1.117$ \\
\hline How well the pharmacist explains what your medications do & 66.7 & 25.6 & 7.7 & $1.74 \pm 1.080$ \\
\hline Interpersonal relationship & 86.7 & 12.3 & 1.0 & $1.85 \pm 0.598$ \\
\hline The pharmacist's interest in your health. & 66.2 & 27.9 & 5.9 & $2.11 \pm 0.947$ \\
\hline The pharmacist's professional relationship with you. & 83.6 & 14.0 & 2.4 & $1.75 \pm 0.805$ \\
\hline The courtesy and respect shown to you by the pharmacy staff. & 83.8 & 13.7 & 2.5 & $1.76 \pm 0.798$ \\
\hline $\begin{array}{l}\text { The help you get from the pharmacist when you have a health problem } \\
\text { related to your medication. }\end{array}$ & 81.1 & 15.9 & 3.0 & $1.77 \pm 0.844$ \\
\hline $\begin{array}{l}\text { The help you get from the pharmacist to avoid unnecessary costs related } \\
\text { to your prescriptions. }\end{array}$ & 59.9 & 32.7 & 7.4 & $2.22 \pm 0.975$ \\
\hline The amount of time the pharmacist offers to spend with you. & 83.4 & 13.8 & 2.8 & $1.82 \pm 0.789$ \\
\hline The pharmacist's instructions about how to take your medication. & 83.5 & 13.3 & 3.2 & $1.75 \pm 0.829$ \\
\hline The professionalism of all the pharmacy staff. & 80.4 & 17.7 & 1.9 & $1.82 \pm 0.796$ \\
\hline The way the pharmacist answers your questions. & 90.1 & 7.8 & 2.1 & $1.63 \pm 0.733$ \\
\hline General satisfaction & 71.3 & 26.5 & 2.2 & $2.02 \pm 0.643$ \\
\hline The privacy of your conversations with the pharmacist. & 53.6 & 29.2 & 17.2 & $2.45 \pm 1.110$ \\
\hline The amount of time it takes to get a prescription filled at your pharmacy. & 83.7 & 13.6 & 2.7 & $1.83 \pm 0.781$ \\
\hline The professional appearance of the pharmacy. & 88.8 & 9.1 & 2.1 & $1.63 \pm 0.765$ \\
\hline Your pharmacy services overall & 88.7 & 9.6 & 1.7 & $1.68 \pm 0.735$ \\
\hline
\end{tabular}

HS - high satisfaction, MS - moderate satisfaction, LS - low satisfaction 
counselling concerning disease treatment or drug-related management of patients is not routine in Slovak community pharmacies. Although according to the actual legislation (Act no. 362/2011), provision expert information and advice on medicines, medical devices and dietetics is an integral part of dispensing process, it does not involve a real continuous longterm and patient-oriented pharmaceutical care. Similarly, different satisfaction was found by Larson (Larson et al. 2002) and Traverso (Traverso et al. 2007), respondents scored items on the managing therapy lower than they did items on the friendly explanation or interpersonal relationship and general satisfaction. These results suggest that better understanding of patient's needs and expectations about his/her treatment management is necessary and should be considered as a key factor in future development and advancing pharmacy practice, leading to higher patient satisfaction. Different dimensions of the pharmacies have been observed that can contribute uniquely to customer satisfaction, with consumer gender contributing greatly toward satisfaction, with type/ location of pharmacy, consumer age and educational degree also playing a part (Petrova et al. 2009).

Community pharmacies are easy available healthcare facilities providing a highly qualified healthcare without any limitations for patients. Pharmacists are usually ranked as one of the most trusted professionals with high level of honesty and ethical principles (European Community Pharmacy Blueprint, 2012). According to our results, community pharmacies in Slovakia are not frequently visited by patients $(82.6 \%$ visited one or two pharmacies per 3 months), but $70.6 \%$ of them had more than one prescription during the last 3 months. On the other hand, $83.3 \%$ of respondents indicated that they needed more than one prescription or OTC medicines during last month. The consumption of drugs in Slovakia is among the highest in Europe. In Slovakia, all prescription and OTC medicines are dispensed only in pharmacies; additional goods (cosmetics, herbal products) people can buy also in the facilities that do not provide health care (e.g. supermarkets). It can explain that the main reason for pharmacy visit was the obtaining of $\mathrm{Rx}$ or OTC medications, similarly as in other published studies (El Hajj et al. 2011, Govo et al. 2008). Counselling or special services were the important reasons for pharmacy visit only for a small number of respondents. It seems that the most Slovak patients perceive pharmacy more as a place where they can get medicines than the place where they can consult and manage their health state. The top factor that affected a patient choice of any pharmacy in our survey was pharmacy location (74.1\%), in accordance with other published findings (El Hajj et al. 2011, Govo et al. 2008). The comparison of factors influencing patient choice of community pharmacy in Poland and in the United Kingdom detected professional and highquality of service as the decisive factors except pharmacy location. Good advice received from the pharmacist and the option of discussing and consulting on all health issues in a consultation room were identified as very important for respondents (Merks et al. 2014). Our respondents positively assessed pharmacist availability and willingness to answer questions, understanding and comprehensible communication with pharmacist, the time pharmacist devotes to them and the current lack of privacy for conversation with pharmacist was identified as item with the lowest patient satisfaction. We suppose that the absence of privacy could be an important barrier for patient counselling with pharmacists and could lead to inadequate managing therapy with lower patient satisfaction.

\section{CONCLUSION}

We may conclude that despite high patient satisfaction with pharmaceutical care provided in Slovak community pharmacies, there is a necessity to redefine the pharmaceutical practice in an effort to modify professional behaviour of community pharmacists in Slovakia and motivate them to promote new components of pharmaceutical care with benefits for patients, pharmacists, healthcare system and society.

\section{ACKNOWLEDGEMEMNTS}

We are grateful to all community pharmacies involving to this research study and Slovak Chamber of Pharmacists for professional guarantee.

\section{References}

[1] Act no. 362/2011 Coll. on drugs and medical devices and on Amendment and Supplement to Certain Acts. (http://www. zakonypreludi.sk/zz/2011-362). Revised December 29, 2012, Effective October 29, 2011. Accessed April 10, 2016.

[2] Alturki M, Khan TM. A study investigating the level of satisfaction with the health services provided by the Pharmacist at ENT hospital, Eastern Region Alahsah, Kingdom of Saudi Arabia. Saudi Pharm J. 2013;21(3):255-260. doi:10.1016/j.jsps.2012.09.001.

[3] Armour C, Bosnic-Anticevich S, Brillant M, et al. Pharmacy Asthma Care Program (PACP) improves outcomes for patients in the community. Thorax. 2007;62(6):496-592. doi:10.1136/ thx.2006.064709.
[4] Cleary PD, McNeil BJ. Patient satisfaction as an indicator of quality care. Inquiry. 1988;25(1):25-36.

[5] El Hajj MS, Salem S, Mansoor H. Public's attitudes towards community pharmacy in Qatar: a pilot study. Patient Prefer Adherence. 2011;5:405-422. doi:10.2147/PPA.S22117.

[6] European Community Pharmacy Blueprint (http://www.pgeu. eu/en/policy/19-the-european-community-pharmacy-blueprint. html). Revised November 15, 2012. Accessed December 15, 2015.

[7] FIP Global Pharmacy Workforce Report 2012, (http://www.fip. org/humanresources). Accessed August 21, 2015.

[8] Garman AN, Garcia J, Hargreaves M. Patient satisfaction as a predictor of return-to-provider behavior: analysis and assessment 
of financial implications. Qual Manag Health Care. 2004;13(1): 75-80.

[9] Govo M, Gavaza P, Maponga CC, Mukosera KT. Community Pharmacy Users'Characteristics, Reasons for Visit to the Pharmacy and Perceptions of the Role of Community Pharmacists in Harare, Zimbabwe. East Cent. Afr. J. Pharm. Sci. 2008;11(1):25-30.

[10] Hasan S, Sulieman H, Stewart K, Chapman CB, Hasan MY, Kong DC. Assessing patient satisfaction with community pharmacy in the UAE using a newly-validated tool. Res Social Adm Pharm. 2013; 9(6):841-50. doi: 10.1016/j.sapharm.2012.10.002.

[11] Health Statistics Yearbook of the Slovak Republic 1999. (http:// www.nczisk.sk/Documents/rocenky/rocenka_1999.pdf). Accessed September 11, 2015

[12] Hepler CD, Strand LM. Opportunities and responsibilities in pharmaceutical care. Am J Hosp Pharm. 1990;47(3):533-543.

[13] Kane RL, Maciejewski M, Finch M. The relationship of patient satisfaction with care and clinical outcomes. Med Care. 1997;35(7):714-730.

[14] Kucukarslan S, Schommer JC. Patients' expectations and their satisfaction with pharmacy services. J Am Pharm Assoc (Wash). 2002;42(3):489-95.

[15] Larson LN, Rovers J, MacKeigan LD. Patient satisfaction with pharmaceutical care: Update of a validated instrument. J Am Pharm Assoc (Wash). 2002;42(1):44-50.

[16] Malovecka I, Papargyris K, Minarikova D, Foltan V, Jankovska A. Impact of new healthcare legislation and price policy on healthcare services provider at the time of financial crisis. A 10 years study. Farmeconomia. Health economics and therapeutic pathways. 2015;16(1):15-24. doi: http://dx.doi.org/10.7175/ fe.v16i1.1040.

[17] Merks P, Kaźmierczak J, Olszewska AE, Kołtowska-Häggström M. Comparison of factors influencing patient choice of community pharmacy in Poland and in the UK, and identification of components of pharmaceutical care. Patient Prefer Adherence. 2014;8:715-726. doi:10.2147/PPA.S53829.

[18] Minarikova D, Malovecka I, Foltan V. Consumer satisfaction with pharmaceutical care in Slovak community pharmacies. Acta Fac. Pharm. Univ. Comen. LXII. 2015; 62(1):1-6. doi: 10.2478/afpuc20140015

[19] Naik Panvelkar P, Saini B, Armour C. Measurement of patient satisfaction with community pharmacy services: a review. Pharm World Sci. 2009;31(5):525-37. doi: 10.1007/s11096-009-9311-2.
[20] Nkansah N, Mostovetsky O, Yu C, et al. Effect of outpatient pharmacists' non-dispensing roles on patient outcomes and prescribing patterns. Cochrane Database of Systematic Reviews 2010;7. CD000336. doi:10.1002/14651858.CD000336.pub2.

[21] Oparah AC, Kikanme LC. Consumer satisfaction with community pharmacies in Warri, Nigeria. Res Social Adm Pharm. 2006; 2(4):499-511.

[22] Petrova G, Clerfeuille F, Vakrilova M, Mitkov C, Poubanne Y. The applicability of the tetraclass model to the management of the patient satisfaction in the pharmacies. Pharm Pract. 2009;7(1): 19-28.

[23] Sitzia J, Wood N. Patient satisfaction: a review of issues and concepts. Soc. Sci. Med. 1997; 45(12):1829-1843.

[24] Slovak Chamber of Pharmacists 2015. (https://www.slek.sk/ lekarne-gis-kraje). Accessed October 20, 2015.

[25] Szalay T, Pažitný P, Szalayová A, et al. Slovakia Health system review. In Health systems in Transition. 2011;13(2):116-119.

[26] Szalayová A, Skybová K, Kandilaki D, Szalay T. Analysis of Pharmaceutical Market in Slovakia and Czech Republic. Develepment over last 10 years. Bratislava: Health Policy Institute, 2014.

[27] Traverso M, Salamano M, Botta C, Colautti M, Palchik V, Perez, B. Questionnaire to assess patient satisfaction with pharmaceutical care in Spanish language. Int J Qual Health Care. 2007;19(4): 217-24.

[28] Van Mil JWF, de Boer WO, Tromp THFJ. European barriers to the implementation of pharmaceutical care. Int J Pharm Prac. 2001;9(3):163-168. doi: 10.1111/j.2042-7174.2001.tb01044.x

[29] Vogler S, Arts D, Sandberger K. Impact of pharmacy deregulation and regulation in European countries: Summary Report. Vienna 2012

[30] Volmer D, Bell JS, Janno R, Raal A, Hamilton DD, Airaksinen MS. Change in public satisfaction with community pharmacy services in Tartu, Estonia, between 1993 and 2005. Res Social Adm Pharm. 2009;5(4):337-46. doi: 10.1016/j.sapharm.2008.12.001.

[31] Ware JE, Davies AE. Behavioral consequences of consumer dissatisfaction with medical care. Eval Program Plann.1983;6(34):291-7.

[32] Zastowny T, Roghmann KJ, Cafferata GL. Patient satisfaction and the use of health services: explorations in causality. Med Care.1989;27(7):705-23. 